\title{
Isolation from oil reservoirs of novel thermophilic anaerobes phylogenetically related to Thermoanaerobacter subterraneus: reassignment of $T$. subterraneus, Thermoanaerobacter yonseiensis, Thermoanaerobacter tengcongensis and Carboxydibrachium pacificum to Caldanaerobacter subterraneus gen. nov., sp. nov., comb. nov. as four novel subspecies
}

\author{
Correspondence \\ Bernard Ollivier \\ ollivier@esil.univ-mrs.fr
}

\author{
Marie-Laure Fardeau, ${ }^{1}$ Monica Bonilla Salinas, ${ }^{1}$ Stéphane L'Haridon, ${ }^{2}$ \\ Christian Jeanthon, ${ }^{2}$ Frédéric Verhé, ${ }^{1}$ Jean-Luc Cayol, ${ }^{1}$ Bharat K. C. Patel, ${ }^{3}$ \\ Jean-Louis Garcia ${ }^{1}$ and Bernard Ollivier ${ }^{1}$ \\ ${ }^{1}$ IRD, UR101 Extrêmophiles, IFR-BAIM, Universités de Provence et de la Méditerranée, \\ ESIL case 925, 163 Avenue de Luminy, 13288 Marseille Cedex 9, France \\ 2UMR CNRS 6539, Institut Universitaire Européen de la Mer, Université de Bretagne \\ Occidentale, 29680 Plouzané, France \\ ${ }^{3}$ School of Biomolecular and Biomedical Sciences, Griffith University, Brisbane, Australia
}

Novel thermophilic, anaerobic, Gram-positive, rod-shaped bacteria, strains SL9 and OCA1, were isolated from oilfields in France and Australia, respectively. Both strains, together with Thermoanaerobacter yonseiensis $\mathrm{KB}-1^{\top}$ (=DSM $\left.13777^{\top}\right)$, Thermoanaerobacter tengcongensis MB4 ${ }^{\top}$ (=DSM $15242^{\top}$ ) and Carboxydibrachium pacificum $\mathrm{JM}^{\top}$ (=DSM $12653^{\top}$ ), possessed genomic (DNA-DNA hybridization studies) and phylogenetic similarities with Thermoanaerobacter subterraneus SEBR $7858^{\top}$ (=DSM $13054^{\top}$ ), which was isolated recently from an oilfield reservoir in south-west France. Marked phenotypic differences exist between the three oilfield isolates ( $T$. subterraneus, strain OCA1 and strain SL9): they include temperature range for growth and substrates used. Differences were also observed in the DNA $G+C$ contents of all organisms. Similarly to $T$. subterraneus, strains SL9 and OCA1, and also T. yonseiensis, T. tengcongensis and Carboxydibrachium pacificum, produced acetate and L-alanine as major end products of glucose metabolism [0.8-1.0 mol L-alanine produced (mol glucose consumed) ${ }^{-1}$ ] and reduced thiosulfate, but not sulfate, to sulfide. Because of these significant metabolic and phylogenetic differences between the oilfield isolates ( $T$. subterraneus, strain OCA1 and strain SL9), T. yonseiensis, T. tengcongensis and Carboxydibrachium pacificum and other Thermoanaerobacter species, it is proposed to reassign them as a novel genus and species, Caldanaerobacter subterraneus gen. nov., sp. nov., comb. nov., with the creation of four novel subspecies, Caldanaerobacter subterraneus subsp. subterraneus subsp. nov., comb. nov., Caldanaerobacter subterraneus subsp. yonseiensis subsp. nov., comb. nov., Caldanaerobacter subterraneus subsp. tengcongensis subsp. nov., comb. nov. and Caldanaerobacter subterraneus subsp. pacificus subsp. nov., comb. nov.
Published online ahead of print on 13 October 2003 as DOI 10.1099/ ijs.0.02711-0.

Abbreviation: RDP, Ribosomal Database Project.

The GenBank/EMBL/DDBJ accession numbers for the 16S rRNA gene sequences of strains OCA1 and SL9 are AY216596 and AY216597, respectively.

\section{INTRODUCTION}

Petroleum reservoirs constitute a group of unique terrestrial sites, as they present an unusual combination of extreme environmental conditions, including temperature, pressure and salinity. It is also known that petroleum composition varies widely between reservoirs, which may 
have an impact on the microbial biodiversity of such environments. Attention has recently been paid to the microbial ecology of petroleum reservoirs, where anaerobes have always been considered to be the dominant micro-organisms. They include fermentative and sulfatereducing bacteria and methanogenic Archaea (Magot et al., 2000). Among the fermentative anaerobes, thermophiles have been studied the most, probably because most oil reservoirs occur at a depth where in situ temperatures exceed $100^{\circ} \mathrm{C}$ (Stetter et al., 1993). Many of them belong to the Bacteria (Jeanthon et al., 1995; Ravot et al., 1995a; Grassia et al., 1996; Fardeau et al., 1997; Rees et al., 1997). They include members of the family 'Thermoanaerobiaceae' (genera Thermoanaerobacter and Thermoanaerobacterium) that were isolated from low-saline reservoirs (Grassia et al., 1996). Most oilfield isolates of the genus Thermoanaerobacter have not been characterized formally, except for two isolates from French hot continental oil reservoirs, with one being identical to Thermoanaerobacter thermohydrosulfuricus (L'Haridon et al., 1995) and the second being a novel species of Thermoanaerobacter: Thermoanaerobacter subterraneus (Fardeau et al., 2000). Several other strains that were isolated from French and African oilfields were recognized as a novel subspecies of Thermoanaerobacter brockii, T. brockii subsp. lactiethylicus (Cayol et al., 1995). Members of the order Thermotogales have also been isolated from oil reservoirs (Stetter et al., 1993). Within this order, novel species of the genera Thermotoga (Jeanthon et al., 1995; Ravot et al., 1995a; Fardeau et al., 1997), Petrotoga and Geotoga (Davey et al., 1993; Lien et al., 1998) have been characterized. Most of these oilfield thermoanaerobes, which belong to the family 'Thermoanaerobiaceae' (Fardeau et al., 1993, 1996) or to the order Thermotogales (Ravot et al., 1995b; Lien et al., 1998), reduced thiosulfate mostly to sulfide. All produced acetate as a major end product of sugar metabolism. L-Alanine production from sugar catabolism by T. subterraneus (Fardeau et al., 2000) and members of the order Thermotogales was of particular interest; this metabolic trait has been interpreted as a possible remnant of an ancestral metabolism (Ravot et al., 1996).

Here, we describe novel thermophilic anaerobes, strains SL9 and OCA1, that were isolated from oil reservoirs in France and Australia and that reduce thiosulfate to sulfide and produce L-alanine from sugar metabolism. Similarily to Carboxydibrachium pacificum (Sokolova et al., 2001), Thermoanaerobacter yonseiensis (Kim et al., 2001) and Thermoanaerobacter tengcongensis (Xue et al., 2001), they share genotypic and phylogenetic similarities with T. subterraneus (Fardeau et al., 2000), which was isolated recently from an oil reservoir in the Paris Basin, France. These six thermoanaerobes are proposed as members of a novel genus of the family 'Thermoanaerobiaceae', Caldanaerobacter gen. nov., comb. nov.

\section{METHODS}

Sample and strain source. Oil-water mixture samples were collected in sterile $250 \mathrm{ml}$ glass bottles from production well-heads in France and Australia through a tapping that was fitted on the production line. Samples were stored at $4{ }^{\circ} \mathrm{C}$ before being used as inocula. Carboxydibrachium pacificum $\mathrm{JM}^{\mathrm{T}}\left(=\mathrm{DSM} 12653^{\mathrm{T}}\right)$, T. yonseiensis KB-1 ${ }^{\mathrm{T}}$ (=DSM $\left.13777^{\mathrm{T}}\right)$, T. brockii DSM $1457^{\mathrm{T}}$ and Thermoanaerobacter ethanolicus DSM $2246^{\mathrm{T}}$ were obtained from the Deutsche Sammlung von Mikroorganismen und Zellkulturen $\mathrm{GmbH}$ (DSMZ), Braunschweig, Germany. T. tengcongensis $\mathrm{MB}^{\mathrm{T}}$ $\left(=\mathrm{DSM} 15242^{\mathrm{T}}\right)$ was provided by the authors.

Media and cultivation conditions. The technique of Hungate (1969) was used throughout this study. Enrichments with oilfield samples were performed in medium that contained (1 distilled water) ${ }^{-1}: 1 \mathrm{~g} \mathrm{NH}_{4} \mathrm{Cl}, 3 \cdot 45 \mathrm{~g}$ PIPES, $0 \cdot 3 \mathrm{~g} \mathrm{~K}_{2} \mathrm{HPO}_{4}, 0 \cdot 3 \mathrm{~g} \mathrm{KH}_{2} \mathrm{PO}_{4}$, $0.2 \mathrm{~g} \mathrm{MgCl}_{2} \cdot 6 \mathrm{H}_{2} \mathrm{O}, 0 \cdot 1 \mathrm{~g} \mathrm{CaCl}_{2} \cdot 2 \mathrm{H}_{2} \mathrm{O}, 15 \mathrm{~g} \mathrm{NaCl}, 0 \cdot 1 \mathrm{~g} \mathrm{KCl}, 0.5 \mathrm{~g}$ sodium acetate, $1 \mathrm{~g}$ glucose, $5 \mathrm{~g}$ yeast extract (Difco), $5 \mathrm{~g}$ bio-trypticase (bioMérieux) and $0.001 \mathrm{~g}$ resazurin. T. subterraneus, T. tengcongensis and $T$. yonseiensis were cultivated in medium that contained $(1 \text { distilled water })^{-1}: 1 \mathrm{~g} \mathrm{NH} \mathrm{N}_{4} \mathrm{Cl}, 0.3 \mathrm{~g} \mathrm{~K}_{2} \mathrm{HPO}_{4}, 0.3 \mathrm{~g} \mathrm{KH}_{2} \mathrm{PO}_{4}$, $0.1 \mathrm{~g} \mathrm{CaCl} 2.2 \mathrm{H}_{2} \mathrm{O}, 0.1 \mathrm{~g} \mathrm{KCl}, 0.5 \mathrm{~g} \mathrm{MgCl}_{2} \cdot 6 \mathrm{H}_{2} \mathrm{O}, 1 \mathrm{~g}$ yeast extract, $2 \mathrm{~g} \mathrm{NaCl}, 3.6 \mathrm{~g}$ glucose, $0.5 \mathrm{~g}$ cysteine/ $\mathrm{HCl}$ and $10 \mathrm{ml}$ trace elements solution (Balch et al., 1979). Carboxydibrachium pacificum was cultivated in the latter medium, modified by replacing $\mathrm{NaCl}$ by $30 \mathrm{~g}$ sea salts and reducing the yeast extract concentration to $0.5 \mathrm{~g} \mathrm{l}^{-1}$. Depending on the medium used, the $\mathrm{pH}$ was adjusted to $7 \cdot 0$ with either $\mathrm{HCl}(5 \mathrm{M})$ or $\mathrm{KOH}(10 \mathrm{M})$. After autoclaving, thiosulfate $(10 \mathrm{mM})$ was added. Aliquots of the medium $(9 \mathrm{ml})$ were then dispensed into Hungate tubes. Prior to inoculation, $\mathrm{Na}_{2} \mathrm{~S} .9 \mathrm{H}_{2} \mathrm{O}$ was injected from sterile stock solutions, to obtain a final concentration of $0 \cdot 1 \%(\mathrm{w} / \mathrm{v})$.

Isolation. Isolation medium $(9 \mathrm{ml})$ was inoculated with $1 \mathrm{ml}$ oilwater mixture, pressurized with $\mathrm{N}_{2}(100 \mathrm{kPa})$ and incubated without shaking at the reservoir temperature $\left(65^{\circ} \mathrm{C}\right)$. Positive enrichments were subcultured and purified by streaking onto plates that contained the same medium, solidified with $0 \cdot 7 \%(\mathrm{w} / \mathrm{v})$ Phytagel (Sigma). Plates were incubated in anaerobic jars pressurized with $\mathrm{N}_{2}(100 \mathrm{kPa})$ at $65^{\circ} \mathrm{C}$ for 3 days. Cultures of T. subterraneus were also incubated at $65^{\circ} \mathrm{C}$, whereas those of $T$. tengcongensis, T. yonseiensis and Carboxydibrachium pacificum were incubated at $70{ }^{\circ} \mathrm{C}$.

Characterization. Temperature, $\mathrm{pH}$ and $\mathrm{NaCl}$ ranges for growth were determined by using the following medium, which contained ${\text { (1 distilled water })^{-1}: 1 \mathrm{~g} \mathrm{NH}}_{4} \mathrm{Cl}, 0.3 \mathrm{~g} \mathrm{~K}_{2} \mathrm{HPO}_{4}, 0.3 \mathrm{~g} \mathrm{KH}_{2} \mathrm{PO}_{4}$, $0.5 \mathrm{~g} \mathrm{MgCl}_{2} \cdot 6 \mathrm{H}_{2} \mathrm{O}, 0 \cdot 1 \mathrm{~g} \mathrm{CaCl}_{2} \cdot 2 \mathrm{H}_{2} \mathrm{O}, 1 \mathrm{~g} \mathrm{NaCl}, 0 \cdot 1 \mathrm{~g} \mathrm{KCl}, 0 \cdot 5 \mathrm{~g}$ cysteine $/ \mathrm{HCl}, 2 \mathrm{~g}$ yeast extract, $0.001 \mathrm{~g}$ resazurin and $10 \mathrm{ml}$ trace elements solution (Balch et al., 1979). In Hungate tubes, medium was adjusted to different $\mathrm{pH}$ values by injecting $\mathrm{NaHCO}_{3}$ or $\mathrm{Na}_{2} \mathrm{CO}_{3}$ from $10 \%(\mathrm{w} / \mathrm{v})$ sterile anaerobic stock solutions. For studies of $\mathrm{NaCl}$ requirements, $\mathrm{NaCl}$ was weighed directly in tubes prior to dispensing the medium. Substrates were tested at a final concentration of $20 \mathrm{mM}$ in enrichment medium. To test for electron acceptors, sodium thiosulfate, sodium sulfate and elemental sulfur were added to the medium at final concentrations of $20 \mathrm{mM}$, $20 \mathrm{mM}$ and $2 \%(\mathrm{w} / \mathrm{v})$, respectively.

Analytical techniques. Growth was measured by inserting tubes directly into a Cary 50 Scan UV-visible spectrophotometer (Varian) and measuring $\mathrm{OD}_{580}$. Sulfide was determined photometrically as colloidal CuS, by using the method of Cord-Ruwisch (1985). $\mathrm{H}_{2}$, $\mathrm{CO}_{2}$, sugars, alcohols and volatile and non-volatile fatty acids were measured as described previously (Fardeau et al., 1996). L-Alanine was measured by HPLC (Moore et al., 1958). Light microscopy was performed as described previously (Fardeau et al., 1997). 
Determination of DNA G+C content. DNA $\mathrm{G}+\mathrm{C}$ content was determined at DSMZ. DNA was isolated and purified by chromatography on hydroxyapatite and its $\mathrm{G}+\mathrm{C}$ content was determined by using HPLC, as described by Mesbah et al. (1989). Non-methylated $\lambda$ DNA (Sigma) was used as the standard.

DNA-DNA hybridization studies. DNA was isolated by chromatography on hydroxyapatite by the procedure of Cashion et al. (1977). DNA-DNA hybridization was performed at DSMZ as described by De Ley et al. (1970), with the modification described by Huss et al. (1983) and Escara \& Hutton (1980), by using a Gilford System model 2600 spectrophotometer equipped with a Gilford model 2527-R thermoprogrammer and plotter. Renaturation rates were computed with the program TRANSFER.BAS (Jahnke, 1992).

$16 S$ rRNA gene sequence analysis. The $16 \mathrm{~S}$ rRNA gene was amplified as described previously (Miranda-Tello et al., 2003). PCR products were cloned by using a pGEM-T Easy cloning kit (Promega), according to the manufacturer's protocols. Clone libraries were screened by direct PCR amplification from a colony by using the vector-specific primers SP6 (5'-ATTTAGGTGACACTATAGAA-3') and T7 (5'-TAATACGACTCACTATAGGG-3') and the following reaction conditions: $2 \mathrm{~min}$ at $96^{\circ} \mathrm{C} ; 40$ cycles of $30 \mathrm{~s}$ at $94{ }^{\circ} \mathrm{C}, 1 \mathrm{~min}$ at $55^{\circ} \mathrm{C}$ and $3 \mathrm{~min}$ at $72^{\circ} \mathrm{C}$; and a final extension of $10 \mathrm{~min}$ at $72^{\circ} \mathrm{C}$. Plasmids that contained an insert of the right length were isolated by using the Wizard Plus SV Minipreps DNA purification system (Promega), according to the manufacturer's protocol. Purified plasmids were sent for sequencing to Genome Express (Grenoble, France). Sequence data were imported into the sequence editor BioEdit version 5.0.9 (Hall, 1999), base-calling was examined and a contiguous consensus sequence was obtained for each isolate. The full sequence was aligned by using the Ribosomal Database Project (RDP)'s Sequence Aligner program (Maidak et al., 2001). The consensus sequence was then adjusted manually to conform to the 16S rRNA secondary structure model (Winker \& Woese, 1991). A non-redundant BLASTN search (Altschul et al., 1997) of the full sequence through GenBank (Benson et al., 1999) identified its closest relatives. Sequences used in phylogenetic analysis were obtained from the RDP (Maidak et al., 2001) and GenBank (Benson et al., 1999). Positions of sequence and alignment ambiguity were omitted and pairwise evolutionary distances, based on 1152 unambiguous nucleotides, were calculated by using the method of Jukes \& Cantor (1969). Dendrograms were constructed by using the neighbourjoining method (Saitou \& Nei, 1987). Confidence in the tree topology was determined by using 100 bootstrapped trees (Felsenstein, 1993). GenBank accession numbers of rDNA sequences from reference organisms are included in Fig. 1.

\section{RESULTS AND DISCUSSION}

Although microaerophilic micro-organisms have been reported to inhabit oil reservoirs (Voordouw et al., 1996), their activities have never been interpreted as significant, as the oil-bearing subsurface is essentially anaerobic. Anaerobes have therefore been considered to be dominant in this ecosystem (Magot et al., 2000). The importance of micro-organisms that are closely related, morphologically and physiologically, to members of the order Thermotogales, namely the genera Thermotoga, Geotoga and Petrotoga, has been established from various hot oil reservoirs throughout the world (Davey et al., 1993; Stetter et al., 1993; Jeanthon et al., 1995; Ravot et al., 1995a; Grassia et al., 1996; Fardeau et al., 1997; Lien et al., 1998; Magot et al., 2000). Members of the family 'Thermoanaerobiaceae', which includes the genera Thermoanaerobacter and Thermoanaerobacterium, were also isolated frequently, in particular from low-saline reservoirs (Cayol et al., 1995; L'Haridon et al., 1995; Grassia et al., 1996; Magot et al., 2000). Species of the genus Thermoanaerobacter reduced thiosulfate to sulfide, whereas those of the genus Thermoanaerobacterium reduced thiosulfate to elemental sulfur. It was reported recently that, similarly to some members of the order Thermotogales (Ravot et al., 1996), a novel species of Thermoanaerobacter, T. subterraneus (Fardeau et al., 2000), also produced L-alanine as a major end product of glucose fermentation. Enrichment cultures that were performed at $65^{\circ} \mathrm{C}$ for 3 days with oil-water mixture samples that originated from oil reservoirs in France and Australia led to the isolation of strains SL9 and OCA1, respectively. Both strains were related phylogenetically to T. subterraneus (Table 1). Strains SL9 and OCA1 were rodshaped bacteria, $0 \cdot 5 \times 2 \cdot 5-8 \cdot 0 \mu \mathrm{m}$, that mostly occurred singly or in pairs. They did not grow in oxidized medium. They grew at temperatures that ranged from 45 to $80^{\circ} \mathrm{C}$ (no growth was obtained at $85^{\circ} \mathrm{C}$ for strain SL9 or at $80^{\circ} \mathrm{C}$ for strain OCA1). At $\mathrm{pH} 7 \cdot 0$, growth was optimum around $75^{\circ} \mathrm{C}$ for strain SL9 and around $70^{\circ} \mathrm{C}$ for strain OCA1 (data not shown). Growth occurred at initial $\mathrm{pH}$ values between $5 \cdot 7$ and $9 \cdot 2$ at $70{ }^{\circ} \mathrm{C}$; the optimum was at $\mathrm{pH} 7 \cdot 0$ (data not shown). The isolates grew in the presence

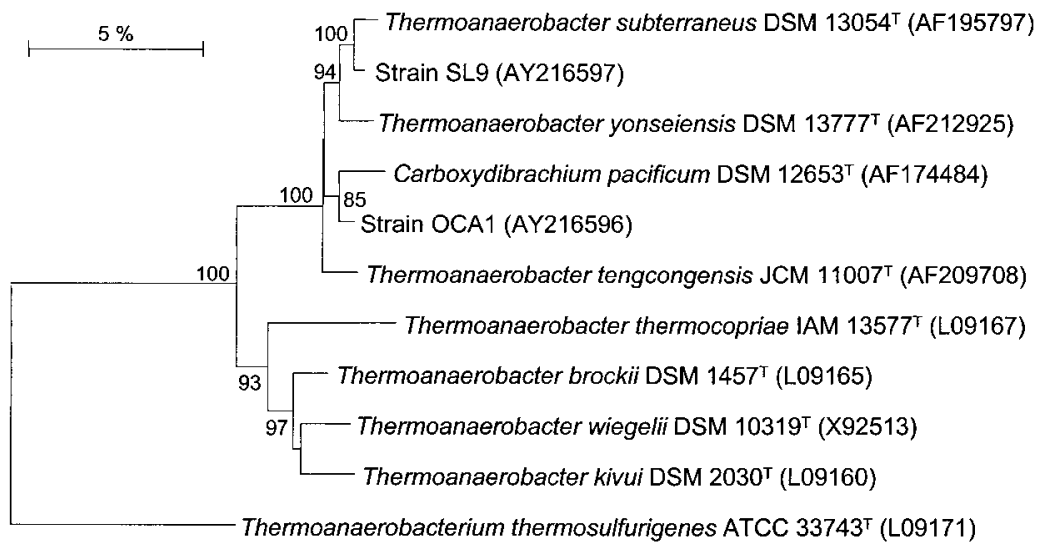

Fig. 1. Dendrogram indicating the position of strains SL9 and OCA1 amongst members of the family 'Thermoanaerobiaceae'. Sequences were obtained from the RDP (Maidak et al., 2001). Bootstrap values, expressed as percentages of 100 replications, are shown at branching points. Only values $>80 \%$ are considered to be significant and reported. Bar, 5 substitutions in 100 nt. 
Table 1. Discriminating characteristics of subspecies of Caldanaerobacter subterraneus gen. nov., sp. nov., comb. nov.

All subspecies produced L-alanine (determined in this study), acetate, $\mathrm{H}_{2}$ and $\mathrm{CO}_{2}$ as diagnostic fermentation products from glucose. + , Positive; -, negative; ND, not determined.

\begin{tabular}{|c|c|c|c|c|}
\hline Characteristic & \multicolumn{4}{|c|}{ Caldanaerobacter subterraneus subspecies } \\
\hline Source & Oil well & Hot spring & Geothermal water & Hydrothermal vent, oil well \\
\hline \multicolumn{5}{|l|}{ Temperature for growth $\left({ }^{\circ} \mathrm{C}\right)$ : } \\
\hline Range & $40-75$ & $50-80$ & $50-85$ & $50-80$ \\
\hline \multicolumn{5}{|l|}{$\mathrm{pH}$ for growth: } \\
\hline Range & $6 \cdot 0-8 \cdot 5$ & $5 \cdot 5-9 \cdot 0$ & $4 \cdot 5-9 \cdot 0$ & $5 \cdot 8-7 \cdot 6$ \\
\hline Optimum & $7 \cdot 5$ & $7 \cdot 0-7 \cdot 5$ & $6 \cdot 5$ & $6 \cdot 8-7 \cdot 2$ \\
\hline \multicolumn{5}{|c|}{$\mathrm{NaCl}$ concentration for growth (\%): } \\
\hline Range & $0-3$ & $0-2 \cdot 5$ & $0-4$ & ND \\
\hline Optimum & 0 & $0 \cdot 2$ & 0 & $2-2 \cdot 5$ \\
\hline Ethanol & - & + & + & - \\
\hline Lactate & + & - & + & - \\
\hline
\end{tabular}

${ }^{*}$ Data from Fardeau et al. (2000).

$\dagger$ Data from Xue et al. (2001).

$\ddagger$ Data from Kim et al. (2001).

§Data from Sokolova et al. (2001).

of $\mathrm{NaCl}$ concentrations that ranged from 0 to $2 \%$. Growth was optimum in the absence of $\mathrm{NaCl}$ at $\mathrm{pH} 7 \cdot 0$ (data not shown). Yeast extract was required for growth on carbohydrates and could not be replaced by vitamins. Strains SL9 and OCA1 grew on the following substrates (at a concentration of $20 \mathrm{mM}$ unless indicated otherwise) in the presence of thiosulfate as the electron acceptor: D-fructose, D-galactose, D-glucose, DL-maltose, D-mannose, D-ribose, starch and glycerol. In contrast to strain OCA1, strain SL9 used cellobiose, lactose, D-xylose and pyruvate and did not use CO. Mannitol, melibiose and xylan were not used by either strain. In the presence of thiosulfate, the glucose metabolic profile of both strains changed dramatically, with an increase in acetate production and disappearance of L-alanine production. Use of valine, isoleucine and leucine was highly enhanced by the presence of thiosulfate. Valine, isoleucine and leucine were oxidized to isobutyrate, 2-methylbutyrate and isovalerate, respectively. Acetate, L-alanine, $\mathrm{H}_{2}$ and $\mathrm{CO}_{2}$ were the major end products of glucose fermentation (in the absence of thiosulfate). Similarly to T. subterraneus, strains SL9 and OCA1 produced around $1 \mathrm{~mol} \mathrm{~L}$-alanine (mol glucose consumed $)^{-1}$. Small amounts of lactate were produced, but no ethanol was produced from glucose fermentation by either strain. Serine was fermented to acetate. These bacteria reduce thiosulfate to sulfide and have a DNA G $+C$ content of $38 \cdot 4$ (strain SL9) and 39.4 (strain OCA1) mol\%.
As well as phylogenetic and phenotypic similarities, strains SL9 and OCA1 share genotypic similarities with T. subterraneus (DNA-DNA hybridization values between $T$. subterraneus and strains SL9 and OCA1 were $92 \cdot 4$ and $78 \cdot 5 \%$, respectively), suggesting that they all belong to the same species. Surprisingly, the closest phylogenetic relatives of T. subterraneus, including Carboxydibrachium pacificum ( $96.8 \%$ sequence similarity), T. tengcongensis ( $97 \cdot 7 \%$ ) and T. yonseiensis (98\%), also presented significant DNA-DNA homology (values $\geqslant 70 \%$ ) with this species (DNA-DNA hybridization values between T. subterraneus and the three species T. tengcongensis, T. yonseiensis and Carboxydibrachium pacificum were $67 \cdot 9,70 \cdot 5$ and $91.0 \%$, respectively; DNA-DNA hybridization values between $T$. tengcongensis and the two species T. yonseiensis and Carboxydibrachium pacificum were $78 \cdot 3$ and $74 \cdot 4 \%$, respectively; DNA-DNA hybridization between $T$. yonseiensis and Carboxydibrachium pacificum was $90.4 \%$ ), so that they should also be considered as members of T. subterraneus (Wayne et al., 1987). Despite phylogenetic and genomic similarities, significant phenotypic differences were found between all these micro-organisms (Table 1), including their DNA $\mathrm{G}+\mathrm{C}$ contents and their ability to oxidize CO. In particular, T. subterraneus, strain OCA1 and strain SL9 have been isolated from oil reservoirs several hundred kilometres apart, thus suggesting that the phenotypical characteristics that distinguish strains SL9 and OCA1 from T. subterraneus 
might have resulted from in situ physicochemical conditions of the oil wells from which they originated. These findings raise questions on the possible indigenous nature of such micro-organisms in the subsurface environment and in oilfield reservoirs, as hypothesized previously by L'Haridon et al. (1995) and Ollivier et al. (1998).

To elucidate the taxonomic status of $T$. subterraneus, strains SL9 and OCA1, Carboxydibrachium pacificum, $T$. yonseiensis and T. tengcongensis, we conducted further experiments to determine whether $\mathrm{L}$-alanine is a major end product of glucose fermentation by the type species of the genus Thermoanaerobacter, T. ethanolicus, and T. brockii, the closest phylogenetic relative of the above bacteria (mean sequence similarity of $93 \%$ ). Both microorganisms are known to be acetate/ethanol/lactate producers (Zeikus et al., 1979; Wiegel \& Ljungdahl, 1981), but have not been reported to produce L-alanine from glucose metabolism. We demonstrated that besides ethanol, T. ethanolicus and T. brockii also produced L-alanine during glucose catabolism [values of $<0 \cdot 2 \mathrm{~mol}$ L-alanine produced (mol glucose consumed) $\left.{ }^{-1}\right]$, but only as a minor end product, compared to T. subterraneus and its phylogenetic relatives (strains SL9 and OCA1, Carboxydibrachium pacificum, T. yonseiensis and T. tengcongensis). Therefore, the metabolic products of sugar fermentation by T. subterraneus, strains SL9 and OCA1, Carboxydibrachium pacificum, T. yonseiensis and T. tengcongensis, which produce significant quantities of alanine [approx. $1 \mathrm{~mol}$ L-alanine produced (mol glucose consumed $)^{-1}$ ], clearly differ from those of T. ethanolicus and $T$. brockii. In addition, all these bacteria constitute a distinct phylogenetic lineage in the family 'Thermoanaerobiaceae (Fig. 1). Most of them ( $T$. tengcongensis, $T$. yonseiensis, Carboxydibrachium pacificum and strain SL9) grow at $80^{\circ} \mathrm{C}$ and are extreme thermophiles, rather than thermophiles. To our knowledge, among the 18 species and subspecies of the genus Thermoanaerobacter, only $T$. tengcongensis $T$. yonseiensis (both to be reclassified this report) and T. brockii grow at $80^{\circ} \mathrm{C}$ (Zeikus et al., 1979; Schmid et al., 1986; Cayol et al., 1995). Due to high DNA homologies (values close to or higher than $70 \%$ ) and high $16 \mathrm{~S}$ rRNA gene sequence similarities, $T$. subterraneus, T. tengcongensis, T. yonseiensis, Carboxydibrachium pacificum, strain OCA1 and strain SL9 should belong to the same species (Wayne et al., 1987). According to Rule 24a (note 3) of the Bacteriological Code (Lapage et al., 1992), Carboxydibrachium pacificum (Sokolova et al., 2001), T. yonseiensis (Kim et al., 2001) and T. tengcongensis (Xue et al., 2001) should be considered as later heterotypic synonyms of T. subterraneus (Fardeau et al., 2000), which has the benefit of anteriority over all these microorganisms. This automatically invalidates the name of the genus Carboxydibrachium. Due to significant phylogenetic and metabolic differences between T. subterraneus and Thermoanaerobacter species, we propose to reassign $T$. subterraneus, strain SL9, strain OCA1, Carboxydibrachium pacificum, T. yonseiensis and T. tengcongensis to a novel genus and species of the family 'Thermoanaerobiaceae', as Caldanaerobacter subterraneus gen. nov., sp. nov., comb. nov. In addition, marked phenotypic differences between these micro-organisms (Table 1) allow clear identification of three novel subspecies of this genus: Caldanaerobacter subterraneus subsp. pacificus subsp. nov., Caldanaerobacter subterraneus subsp. yonseiensis subsp. nov. and Caldanaerobacter subterraneus subsp. tengcongensis subsp. nov. This automatically places the type strain of $T$. subterraneus (DSM $13054^{\mathrm{T}}$ ) as the type strain of Caldanaerobacter subterraneus subsp. subterraneus subsp. nov. According to Fig. 1, strains SL9 and OCA1 are related phylogenetically to Caldanaerobacter subterraneus subsp. subterraneus and Caldanaerobacter subterraneus subsp. pacificus, respectively.

\section{Description of Caldanaerobacter gen. nov.}

Caldanaerobacter (cal.da.nae.ro.bac'ter. L. adj. caldus hot; Gr. pref. an not; Gr. n. aer air; N.L. masc. n. bacter equivalent of Gr. neut. n. bakterion rod, staff; N.L. masc. n. Caldanaerobacter rod that grows in the absence of air at high temperatures).

Cells are straight rods. Gram-reaction is positive or negative. Endospores may be observed. Growth is strictly anaerobic. Thermophilic, fermentative member of the domain Bacteria, family 'Thermoanaerobiaceae'. Carbohydrates serve as fermentable substrates, with acetate and L-alanine as major end products. Approximately $1 \mathrm{~mol}$ L-alanine (mol glucose fermented) ${ }^{-1}$ is produced. DNA $\mathrm{G}+\mathrm{C}$ content is $33-41 \mathrm{~mol} \%$. The type species is Caldanaerobacter subterraneus.

\section{Description of Caldanaerobacter subterraneus sp. nov., comb. nov.}

Caldanaerobacter subterraneus (sub.ter.ra' ne.us. L. pref. sub less than; L. n. terra earth; L. masc. adj. subterraneus underground, subterranean, describing its site of isolation).

Basonym: Thermoanaerobacter subterraneus Fardeau et al. 2000.

Same description as that given for the genus. Acetate, L-alanine, lactate, $\mathrm{H}_{2}$ and $\mathrm{CO}_{2}$ are produced during glucose fermentation. Thiosulfate, but not sulfate, is used as an electron acceptor.

The type strain is DSM $13054^{\mathrm{T}}\left(=\mathrm{CNCM} \mathrm{I-2383^{ \textrm {T } }}\right)$.

\section{Description of Caldanaerobacter subterraneus subsp. subterraneus subsp. nov.}

Caldanaerobacter subterraneus subsp. subterraneus (sub. ter.ra'ne.us. L. pref. sub less than; L. n. terra earth; L. masc. adj. subterraneus underground, subterranean, describing its site of isolation).

Rods $(0 \cdot 5-0 \cdot 7 \times 2-8 \mu \mathrm{m})$ that occur singly or in pairs and possess laterally inserted flagella. Spores are not observed under microscopic examination, but cultures exposed to 
$120^{\circ} \mathrm{C}$ for $45 \mathrm{~min}$ can be subcultured, indicating the presence of heat-resistant forms. Electron microscopic examination reveals a Gram-positive cell wall. Round colonies ( $3 \mathrm{~mm}$ in diameter) develop on Phytagel plates or in roll-tubes after 3 days incubation at $70^{\circ} \mathrm{C}$. Chemoorganotrophic and obligately anaerobic member of the domain Bacteria, family 'Thermoanaerobiaceae'. Thermophilic. Optimum temperature for growth is $65-75^{\circ} \mathrm{C}$ at $\mathrm{pH} 7 \cdot 5$; temperature range for growth is $40-80^{\circ} \mathrm{C}$. Optimum $\mathrm{pH}$ is $7 \cdot 0-7 \cdot 5$; growth occurs between $\mathrm{pH} 5 \cdot 7$ and 9.2. Halotolerant; grows in the presence of up to $3 \%$ $\mathrm{NaCl}$. Yeast extract or bio-trypticase is required for growth on carbohydrates. Growth on sugars is highly enhanced by the presence of both yeast extract and bio-trypticase. Yeast extract cannot be replaced by vitamins. Ferments cellobiose, D-fructose, D-galactose, D-glucose, DL-lactose, DL-maltose, D-mannose, melibiose, D-ribose, starch, Dxylose, glycerol, mannitol, pyruvate and xylan. L-Arabinose, L-rhamnose, sorbose, sucrose, L-xylose and $\mathrm{CO}$ are not used. Acetate, L-alanine, lactate, $\mathrm{H}_{2}$ and $\mathrm{CO}_{2}$ are produced during glucose fermentation. Elemental sulfur, thiosulfate and sulfite, but not sulfate, are used as electron acceptors. DNA G + C content is $38 \cdot 4-41 \mathrm{~mol} \%$ (as determined by HPLC).

The type strain is SEBR $7858^{\mathrm{T}}\left(=\mathrm{CNCM} \mathrm{I}-2383^{\mathrm{T}}=\mathrm{DSM}\right.$ $\left.13054^{\mathrm{T}}\right)$. Isolated from oilfield waters.

\section{Description of Caldanaerobacter subterraneus subsp. tengcongensis subsp. nov., comb. nov.}

Caldanaerobacter subterraneus subsp. tengcongensis (teng.con.gen'sis. N.L. masc. adj. tengcongensis pertaining to Tengcong, China).

Basonym: Thermoanaerobacter tengcongensis Xue et al. 2001.

Description as that given by Xue et al. (2001). Approximately $1 \mathrm{~mol} \mathrm{~L}$-alanine (mol glucose fermented $)^{-1}$ is produced. Oxidizes CO.

The type strain is $\mathrm{MB}^{\mathrm{T}}\left(=\mathrm{JCM} 11007^{\mathrm{T}}=\mathrm{DSM} 15242^{\mathrm{T}}\right)$.

\section{Description of Caldanaerobacter subterraneus subsp. yonseiensis subsp. nov., comb. nov.}

Caldanaerobacter subterraneus subsp. yonseiensis (yon.sei.en'sis. N.L. adj. yonseiensis pertaining to Yonsei University, Seoul, Korea, in recognition of its support of research into extreme thermophiles and their thermostable enzymes).

Basonym: Thermoanaerobacter yonseiensis Kim et al. 2001.

Description as that given by Kim et al. (2001). Approximately $1 \mathrm{~mol}$ L-alanine (mol glucose fermented) ${ }^{-1}$ is produced. Oxidizes CO.

The type strain is KB-1 $1^{\mathrm{T}}\left(=\mathrm{KFCC} 11116^{\mathrm{T}}=\right.$ DSM $\left.13777^{\mathrm{T}}\right)$.

\section{Description of Caldanaerobacter subterraneus subsp. pacificus subsp. nov., comb. nov.}

Caldanaerobacter subterraneus subsp. pacificus (pa.ci'fi.cus. L. masc. adj. pacificus peaceful; pertaining to the Pacific Ocean, from the western part of which the type strain was isolated).

Basonym: Carboxydibrachium pacificum Sokolova et al. 2001.

Description as that given by Sokolova et al. (2001). Approximately $1 \mathrm{~mol} \mathrm{~L}$-alanine (mol glucose fermented $)^{-1}$ is produced. Reduces thiosulfate to sulfide. Oxidizes CO.

The type strain is $\mathrm{JM}^{\mathrm{T}}\left(=\mathrm{DSM} 12653^{\mathrm{T}}\right)$. Isolated from a submarine hot vent.

\section{ACKNOWLEDGEMENTS}

We gratefully acknowledge F. Le Garrec (Coparex Production) for his assistance in sampling procedures, J. Euzéby for taxonomic comments, P. Thomas for his comments regarding electron microscopic examinations and P. Roger for improving the manuscript. Funding from the Australian Research Council to B. K. C. P. and B. O. is gratefully acknowledged.

\section{REFERENCES}

Altschul, S. F., Madden, T. L., Schäffer, A. A., Zhang, J., Zhang, Z., Miller, W. \& Lipman, D. J. (1997). Gapped BLAST and PSI-BLAST: a new generation of protein database search programs. Nucleic Acids Res 25, 3389-3402.

Balch, W. E., Fox, G. E., Magrum, L. J., Woese, C. R. \& Wolfe, R. S. (1979). Methanogens: reevaluation of a unique biological group. Microbiol Rev 43, 260-296.

Benson, D. A., Boguski, M. S., Lipman, D. J., Ostell, J., Oullette, B. F. F., Rapp, B. A. \& Wheeler, D. L. (1999). GenBank. Nucleic Acids Res 27, 12-17.

Cashion, P., Holder-Franklin, M. A., McCully, J. \& Franklin, M. (1977). A rapid method for the base ratio determination of bacterial DNA. Anal Biochem 81, 461-466.

Cayol, J.-L., Ollivier, B., Patel, B. K. C., Ravot, G., Magot, M., Ageron, E., Grimont, P. A. D. \& Garcia, J.-L. (1995). Description of Thermoanaerobacter brockii subsp. lactiethylicus subsp. nov., isolated from a deep subsurface French oil well, a proposal to reclassify Thermoanaerobacter finnii as Thermoanaerobacter brockii subsp. finnii comb. nov., and an emended description of Thermoanaerobacter brockii. Int J Syst Bacteriol 45, 783-789.

Cord-Ruwisch, R. (1985). A quick method for the determination of dissolved and precipitated sulfides in cultures of sulfate-reducing bacteria. J Microbiol Methods 4, 33-36.

Davey, M. E., Wood, W. A., Key, R., Nakamura, K. \& Stahl, D. (1993). Isolation of three species of Geotoga and Petrotoga: two new genera, representing a new lineage in the bacterial line of descent distantly related to the "Thermotogales". Syst Appl Microbiol 16, 191-200.

De Ley, J., Cattoir, H. \& Reynaerts, A. (1970). The quantitative measurement of DNA hybridization from renaturation rates. Eur $J$ Biochem 12, 133-142.

Escara, J. F. \& Hutton, J. R. (1980). Thermal stability and renaturation of DNA in dimethyl sulfoxide solutions: acceleration of the renaturation rate. Biopolymers 19, 1315-1327. 
Fardeau, M.-L., Cayol, J.-L., Magot, M. \& Ollivier, B. (1993). $\mathrm{H}_{2}$ oxidation in the presence of thiosulfate, by a Thermoanaerobacter strain isolated from an oil-producing well. FEMS Microbiol Lett 113, 327-332.

Fardeau, M.-L., Faudon, C., Cayol, J.-L., Magot, M., Patel, B. K. C. \& Ollivier, B. (1996). Effect of thiosulphate as electron acceptor on glucose and xylose oxidation by Thermoanaerobacter finnii and a Thermoanaerobacter sp. isolated from oil field water. Res Microbiol 147, 159-165.

Fardeau, M.-L., Ollivier, B., Patel, B. K. C., Magot, M., Thomas, P., Rimbault, A., Rocchiccioli, F. \& Garcia, J.-L. (1997). Thermotoga hypogea sp. nov., a xylanolytic, thermophilic bacterium from an oilproducing well. Int J Syst Bacteriol 47, 1013-1019.

Fardeau, M.-L., Magot, M., Patel, B. K. C., Thomas, P., Garcia, J.-L. \& Ollivier, B. (2000). Thermoanaerobacter subterraneus sp. nov., a novel thermophile isolated from oilfield water. Int J Syst Evol Microbiol 50, 2141-2149.

Felsenstein, J. (1993). PHYLIP (phylogeny inference package), version 3.5c. Department of Genetics, University of Washington, Seattle, USA.

Grassia, G. S., McLean, K. M., Glénat, P., Bauld, J. \& Sheehy, A. J. (1996). A systematic survey for thermophilic fermentative bacteria and archaea in high temperature petroleum reservoirs. FEMS Microbiol Ecol 21, 47-58.

Hall, T. A. (1999). BioEdit: a user-friendly biological sequence alignment editor and analysis program for Windows 95/98/NT. Nucleic Acids Symp Ser 41, 95-98.

Hungate, R. E. (1969). A roll-tube method for the cultivation of strict anaerobes. Methods Microbiol 3B, 117-132.

Huss, V. A. R., Festl, H. \& Schleifer, K.-H. (1983). Studies on the spectrophotometric determination of DNA hybridization from renaturation rates. Syst Appl Microbiol 4, 184-192.

Jahnke, K.-D. (1992). Basic computer program for evaluation of spectroscopic DNA renaturation data from GILFORD system 2600 spectrometer on a PC/XT/AT type personal computer. J Microbiol Methods 15, 61-73.

Jeanthon, C., Reysenbach, A.-L., L'Haridon, S., Gambacorta, A., Pace, N. R., Glénat, P. \& Prieur, D. (1995). Thermotoga subterranea sp. nov., a new thermophilic bacterium isolated from a continental oil reservoir. Arch Microbiol 164, 91-97.

Jukes, T. H. \& Cantor, C. R. (1969). Evolution of protein molecules. In Mammalian Protein Metabolism, pp. 21-132. Edited by H. N. Munro. New York: Academic Press.

Kim, B.-C., Grote, R., Lee, D.-W., Antranikian, G. \& Pyun, Y.-R. (2001). Thermoanaerobacter yonseiensis sp. nov., a novel extremely thermophilic, xylose-utilizing bacterium that grows at up to $85^{\circ} \mathrm{C}$. Int J Syst Evol Microbiol 51, 1539-1548.

Lapage, S. P., Sneath, P. H. A., Lessel, E. F., Skerman, V. B. D., Seeliger, H. P. R. \& Clark, W. A. (editors) (1992). International Code of Nomenclature of Bacteria (1990 Revision). Bacteriological Code. Washington, DC: American Society for Microbiology.

L'Haridon, S., Reysenbach, A.-L., Glénat, P., Prieur, D. \& Jeanthon, C. (1995). Hot subterranean biosphere in a continental oil reservoir. Nature 377, 223-224.

Lien, T., Madsen, M., Rainey, F. A. \& Birkeland, N.-K. (1998). Petrotoga mobilis sp. nov., from a North Sea oil-production well. Int $J$ Syst Bacteriol 48, 1007-1013.

Magot, M., Ollivier, B. \& Patel, B. K. C. (2000). Microbiology of petroleum reservoirs. Antonie van Leeuwenhoek 77, 103-116.

Maidak, B. L., Cole, J. R., Lilburn, T. G. \& 7 other authors (2001). The RDP-II (Ribosomal Database Project). Nucleic Acids Res 29, 173-174.
Mesbah, M., Premachandran, U. \& Whitman, W. B. (1989). Precise measurement of the $\mathrm{G}+\mathrm{C}$ content of deoxyribonucleic acid by high-performance liquid chromatography. Int J Syst Bacteriol 39, 159-167.

Miranda-Tello, E., Fardeau, M.-L., Fernández, L., Ramírez, F., Cayol, J.-L., Thomas, P., Garcia, J.-L. \& Ollivier, B. (2003). Desulfovibrio capillatus sp. nov., a novel sulfate-reducing bacterium isolated from an oil field separator located in the Gulf of Mexico. Anaerobe 9, 97-103.

Moore, S., Spackman, D. H. \& Stein, W. H. (1958). Chromatography of amino acids on sulfonated polystyrene resins. An improved system. Anal Chem 30, 1185-1190.

Ollivier, B., Fardeau, M.-L., Cayol, J.-L., Magot, M., Patel, B. K. C., Prensier, G. \& Garcia, J.-L. (1998). Methanocalculus halotolerans gen. nov., sp. nov., isolated from an oil-producing well. Int J Syst Bacteriol 48, 821-828.

Ravot, G., Magot, M., Fardeau, M.-L., Patel, B. K. C., Prensier, G., Egan, A., Garcia, J.-L. \& Ollivier, B. (1995a). Thermotoga elfii sp. nov., a novel thermophilic bacterium from an African oilproducing well. Int J Syst Bacteriol 45, 308-314.

Ravot, G., Ollivier, B., Magot, M., Patel, B. K. C., Crolet, J.-L., Fardeau, M.-L. \& Garcia, J.-L. (1995b). Thiosulfate reduction, an important physiological feature shared by members of the order Thermotogales. Appl Environ Microbiol 61, 2053-2055.

Ravot, G., Ollivier, B., Fardeau, M.-L., Patel, B. K. C., Andrews, K. T., Magot, M. \& Garcia, J.-L. (1996). L-Alanine production from glucose fermentation by hyperthermophilic members of the domains Bacteria and Archaea: a remnant of an ancestral metabolism? Appl Environ Microbiol 62, 2657-2659.

Rees, G. N., Patel, B. K. C., Grassia, G. S. \& Sheehy, A. J. (1997). Anaerobaculum thermoterrenum gen. nov., sp. nov., a novel, thermophilic bacterium which ferments citrate. Int J Syst Bacteriol 47, 150-154.

Saitou, N. \& Nei, M. (1987). The neighbor-joining method: a new method for reconstructing phylogenetic trees. Mol Biol Evol 4, 406-425.

Schmid, U., Giesel, H., Schoberth, S. M. \& Sahm, H. (1986). Thermoanaerobacter finnii spec. nov., a new ethanologenic sporogenous bacterium. Syst Appl Microbiol 8, 80-85.

Sokolova, T. G., González, J. M., Kostrikina, N. A., Chernyh, N. A., Tourova, T. P., Kato, C., Bonch-Osmolovskaya, E. A. \& Robb, F. T. (2001). Carboxydobrachium pacificum gen. nov., sp. nov., a new anaerobic, thermophilic, CO-utilizing marine bacterium from Okinawa Trough. Int J Syst Evol Microbiol 51, 141-149.

Stetter, K. O., Huber, R., Blöchl, E., Kurr, M., Eden, R. D., Fielder, M., Cash, H. \& Vance, I. (1993). Hyperthermophilic archaea are thriving in deep North Sea and Alaskan oil reservoirs. Nature 365, 743-745.

Voordouw, G., Armstrong, S. M., Reimer, M. F., Fouts, B., Telang, A. J., Shen, Y. \& Gevertz, D. (1996). Characterization of $16 \mathrm{~S}$ rRNA genes from oil field microbial communities indicates the presence of a variety of sulfate-reducing, fermentative, and sulfide-oxidizing bacteria. Appl Environ Microbiol 62, 1623-1629.

Wayne, L. G., Brenner, D. J., Colwell, R. R. \& 9 other authors (1987). International Committee on Systematic Bacteriology. Report of the ad hoc committee on reconciliation of approaches to bacterial systematics. Int J Syst Bacteriol 37, 463-464.

Wiegel, J. \& Ljungdahl, L. G. (1981). Thermoanaerobacter ethanolicus gen. nov., spec. nov., a new, extreme thermophilic, anaerobic bacterium. Arch Microbiol 128, 343-348. 
Winker, S. \& Woese, C. R. (1991). A definition of the domains Archaea, Bacteria and Eucarya in terms of small subunit ribosomal RNA characteristics. Syst Appl Microbiol 14, 305-310.

Xue, Y., Xu, Y., Liu, Y., Ma, Y. \& Zhou, P. (2001). Thermoanaerobacter tengcongensis sp. nov., a novel anaerobic, saccharolytic, thermophilic bacterium isolated from a hot spring in Tengcong, China. Int J Syst Evol Microbiol 51, 1335-1341.

Zeikus, J. G., Hegge, P. W. \& Anderson, M. A. (1979). Thermoanaerobium brockii gen. nov. and sp. nov., a new chemoorganotrophic, caldoactive, anaerobic bacterium. Arch Microbiol 122, 41-48. 